\title{
Analysis of Type Cover on Drying Rate and Moisture Content In Seaweed Solar Dryer
}

\author{
Mietra Anggara ${ }^{*}, \operatorname{Irfan}^{2}$ \\ 1,2 Mechanical Engineering, Universitas Teknologi Sumbawa. \\ Universitas Teknologi Sumbawa, Sumbawa, West Nusa Tenggara, Indonesia. \\ ${ }^{*}$ Corresponding author: \\ Email: mietra.anggara@uts.ac.id
}

\begin{abstract}
.
Seaweed is one of the marine commodities that has high economic value and benefits for humans, because seaweed can be processed into basic food ingredients and various types of products such as seaweed lunkhead, gelatin, cosmetic medicines and so on. The post-harvest handling process for the Papuan community, Kec. Taliwang, West Sumbawa Regency (NTB) is still done traditionally so natural drying usually takes a long time because the temperature and energy depend on sunlight. This will lead to a decline in the quality of seaweed products because temperature and energy depend on sunlight. One of the efforts to improve the quality of seaweed production is to reduce the water content, the maximum water content limit, which meets SNI 25\% - 50\%. In this study, four forms of cover were used, namely the cover form of a single oblique solar dryer, the cover form of the taper solar dryer, the cover form of the double slanted solar dryer, the cover form of the rectangular prism solar dryer. The peak drying rate lies on a double sloping cover of $0.40 \mathrm{~g} /$ minute, a taper cover of $0.37 \mathrm{~g} /$ minute, a rectangular prism cover of $0.34 \mathrm{~g} /$ minute and a single sloping cover of $0.30 \mathrm{~g} /$ minute. The hot peaks that are useful are located on a double sloping cover of 3.82 Watt, a taper cover of 2.80 Watt, a rectangular prism cover of 2.09 Watt and a single cover of 0.46 Watt. The peak of efficiency lies in the double sloping cover of $8.57 \%$, taper cover of $6.28 \%$, rectangular prism cover of $4.69 \%$ and single sloping cover of $2.28 \%$. The peak of seaweed residual water content lies on a double sloping cover of $13.21 \%$, a taper cover of $19.61 \%$, a rectangular prism cover of 25.73 and a double sloping cover of $27.75 \%$. This shows that drying using double sloping covers is more effective and efficient, so it can accelerate the drying rate and can increase the selling price of seaweed for seaweed farmers in Kertasari Village, Taliwang District, West Sumbawa (NTB.)
\end{abstract}

Keywords: Cover Solar Dryer, Moisture Content, Drying Rate, Efficiency

\section{INTRODUCTION}

Basically, solar dryer requires a solar collector to collect heat and convert it into heat energy for the drying process. As for several types of solar dryer covers that have been carried out by previous studies, generally use rectangular prism covers, taper covers, single slanted covers, double slanted covers and flat covers. Based on this background, research on cover has been carried out in the design and manufacture of a

http://ijstm.inarah.co.id 
solar powered fish dryer system with a flat cover model with a maximum temperature of $50^{\circ} \mathrm{C}$ with a maximum outside temperature of $38^{\circ} \mathrm{C}$ [1]. Analysis of the solar collector's corrugated plate drying frangipani flower on a rectangular prism-shaped cover that solar radiation hitting the transparent cover will penetrate the transparent cover and hit the corrugated plate that has been painted black. Inside the collector, solar radiation will be reflected repeatedly due to the wavy cover and collector. The incoming air will hit the hot absorbent plate and transfer the heat from the plate to the drying chamber. The test material will experience a decrease in water content and make the test material undergo a drying process. Furthermore, the hot air will be released through the chimney above the dryer cover. From the conclusion that the peak energy of the fluid is $0.04 \mathrm{kj} / \mathrm{s}$, the useful energy absorbed by the collector is 0.0153 $\mathrm{kg} / \mathrm{d}$ and an average efficiency of $0.64 \%$ [2].

Furthermore, an experimental study of the shape of the solar still cover glass, the temperature of the absorbent plate using a double sloping cover has a higher temperature than the flat cover. This condition is caused by the double sloping cover having a closer distance from the absorbent plate to heat the material [3]. In the tapershaped solar cover salted fish dryer, the temperature distribution during the experiment had a relatively uniform pattern with an average room temperature range of $53^{\circ} \mathrm{C}$ in the $45^{\circ} \mathrm{C}-60^{\circ} \mathrm{C}$ range and having a drying efficiency of $26.15 \%$ [4]. In addition, research is being conducted on the effect of glass spacing and solar still solar heat absorber. In his research, the largest solar radiation that can be transmitted is at a distance of glass with a heat absorber as far as $20 \mathrm{~cm}$ [5]. Furthermore, the design and testing of solar powered fish dryers with evacuated tube collector modeling with the air temperature in the drying chamber is $35-70^{\circ} \mathrm{C}$. Overall, the average value of the collector temperature in the drying chamber is strongly influenced by the radiation intensity that heats the collector [6].

This condition led to the idea of analyzing the Cover Shape Variation of the Solar Dryer in the Seaweed Dryer, which varies, among others, with a single oblique cover, taper cover, double slanted cover and a rectangular prism cover. This aims to obtain an effective cover form and increase the efficient and effective collector temperature and accelerate and increase the drying rate of the seaweed.

\section{METHODS}

\section{Research variable}

This study will examine variations in the cover shape of the seaweed dryer solar dryer. After the preparation is complete, a variation of the cover solar dryer is tested by observing and recording and retrieving data with the measuring instrument that has been installed. Seaweed will be used as research material. The fresh water content of the seaweed is around $85 \%$, and the water content of the dried seaweed is in accordance with the SNI provisions, which is around a maximum of $25 \%-50 \%$. With 
an initial mass of $300 \mathrm{~g}$ in each variation of the cover shape of the seaweed dryer solar dryer.

\section{Research Design}
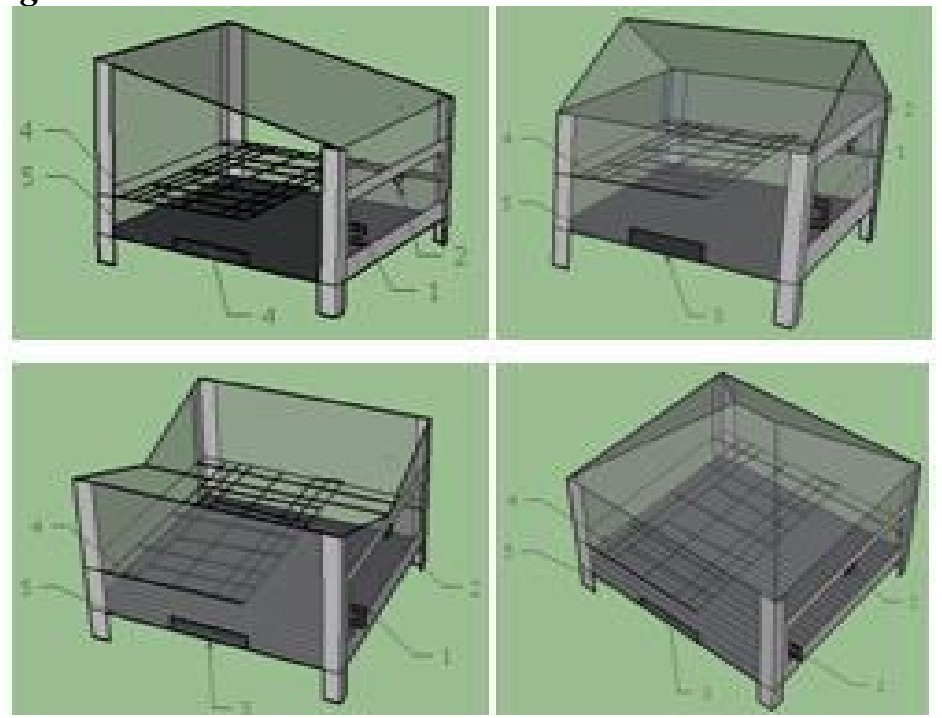

Fig 1. Variations of Cover Solar Dryer Seaweed Dryer Caption :

1. Door Handle

2. Air ventilation out

3. Air intake ventilation

4. Iron net (seaweed drying mat).

5. Collector plates (absorber).

\section{Data Retrieval Procedure}

Data processing starts at 10:00 to 14:00 Wita in sunny weather conditions with the following procedure. The initial stage is to put 4 solar dryers under direct solar radiation, and position them according to the sun's direction for the Sumbawa area with a position of $9.7^{\circ} \mathrm{S}$ and $118.22^{\circ}$ East for May - June 2020. The position of the sun will tend to be in the north latitude., so that the solar dryer is positioned facing north south. Then the seaweed is put into a solar dryer with a predetermined amount, no seaweed is added within a period of one day. This is to find out the amount of water content in seaweed that decreases in one day. Next, make gradual measurements every 1 hour interval of the intensity of solar radiation, environmental temperature, and the temperature of the absorbent plate. Then measure the amount of reduced water content of seaweed for one day. The final stage is repetition of the test to get optimal results. 


\section{RESULT AND DISCUSSION}

\section{Field Test Results}

The following is a graph - a graph of the measurement results that have been carried out in June 2020. For measurements of temperature and water content, it is taken from 10:00 - 14:00 Wita

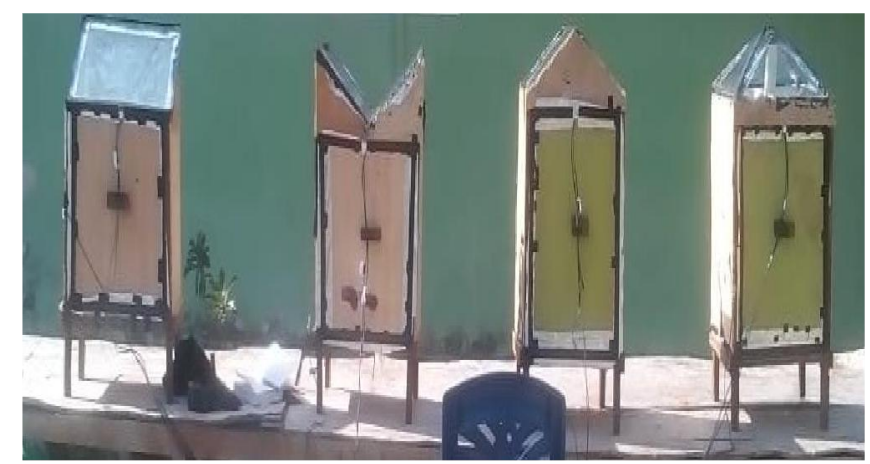

Fig 2. Variations in the form of Cover Solar Dryer Seaweed Dryer

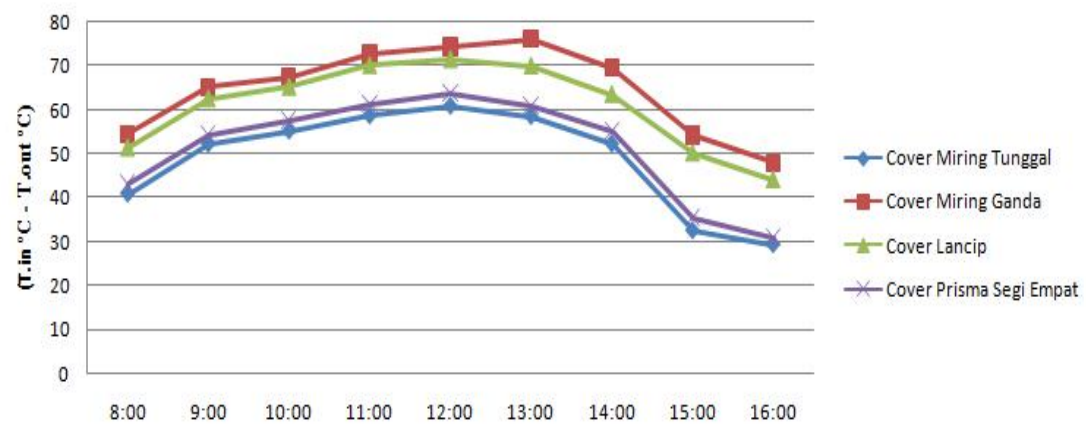

Fig 3.Temperature Testing Graph 5 June 2020

Figure 3 shows the temperature data for the variation in the cover shape of the solar dryer for drying seaweed. The first test was carried out on June 5, 2020, the first test data collection was carried out for three days. The highest temperature peak is located at 1:00 p.m. for solar dryer with double sloping cover, the temperature is $76.08^{\circ} \mathrm{C}$, useful heat is 0.48 Watt, and efficiency is $1.13 \%$. The temperature of the Taper Cover solar dryer is $70.06{ }^{\circ} \mathrm{C}$, useful heat 0.33 Watt, efficiency $0.78 \%$. Solar dryer with prism cover form $60.88{ }^{\circ} \mathrm{C}$, useful heat 0.28 Watt, $0.66 \%$ efficiency and single sloping cover solar dryer temperature temperature $58.48^{\circ} \mathrm{C}$, useful heat $0.26 \mathrm{Watt}$, efficiency $0.61 \%$. 


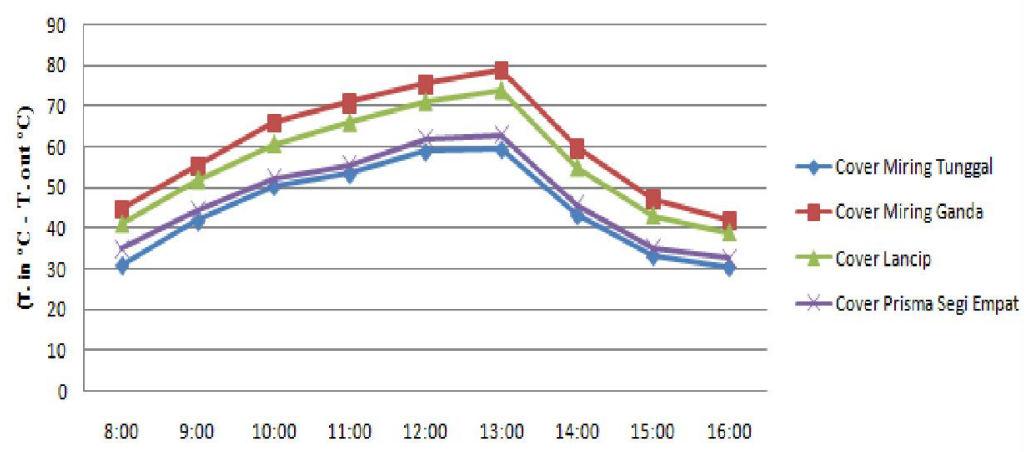

Fig 4.Temperature Testing Graph 6 June 2020

Testing on June 6,2020, the test data collection is at 08:00 - 16:00 WITA, the highest peak is at 13:00, namely on the cover of the double tilted solar dryer, temperature temperature is $78.88^{\circ} \mathrm{C}$, useful heat 1.58 Watt, efficiency $4.47 \%$. Solar dryer with taper cover, temperature $73.96{ }^{\circ} \mathrm{C}$, useful heat 1.12 Watt, efficiency $3.17 \%$. Solar dryer in the form of a rectangular prism cover, temperature $62.78{ }^{\circ} \mathrm{C}$, useful heat $0.18 \mathrm{Watt}$, efficiency $0.50 \%$. Single oblique cover solar dryer temperature $59.42{ }^{\circ} \mathrm{C}$, useful heat 0.20 Watt, efficiency $0.56 \%$.

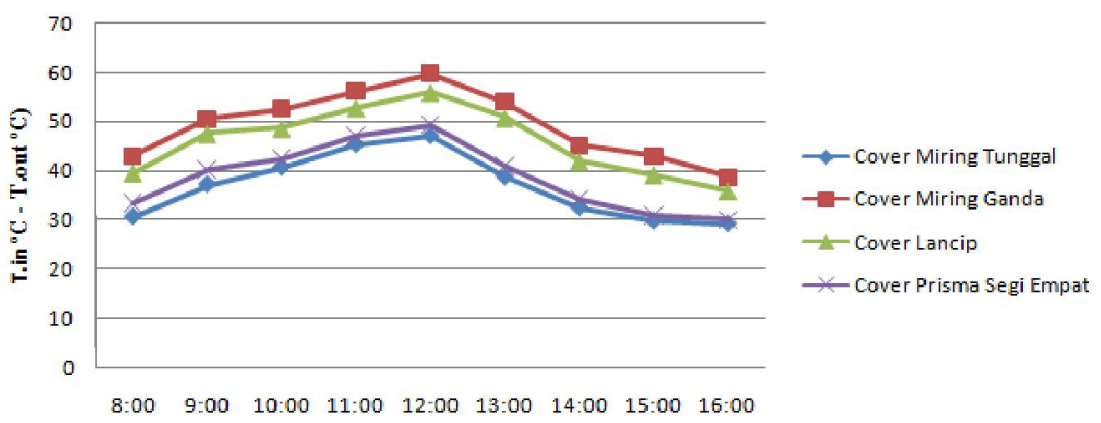

Fig 5.Temperature Testing Graph 7 June 2020

Testing on June 7, 2020 data collection at 10:00 - 16:00 WIB. The peak of the highest temperature is at 12:00 noon on a double sloping solar dryer with a temperature of $59.73{ }^{\circ} \mathrm{C}$, useful heat 2.13 Watt, efficiency $4.63 \%$. Solar dryer with taper cover at 12:00 noon, temperature temperature of $55.97{ }^{\circ} \mathrm{C}, 1.46$ Watt, efficiency $3.18 \%$. Solar dryer in the form of a cover prism, temperature temperature of $49.3{ }^{\circ} \mathrm{C}$, useful heat 0.69 Watt, efficiency $1.50 \%$. Solar dryer with a single oblique cover, the temperature at 12:00 noon is smaller than the other covers, the temperature is $47.16^{\circ} \mathrm{C}$, useful heat is 0.32 Watts, and efficiency is $0.69 \%$. 


\section{Drying Rate Testing}

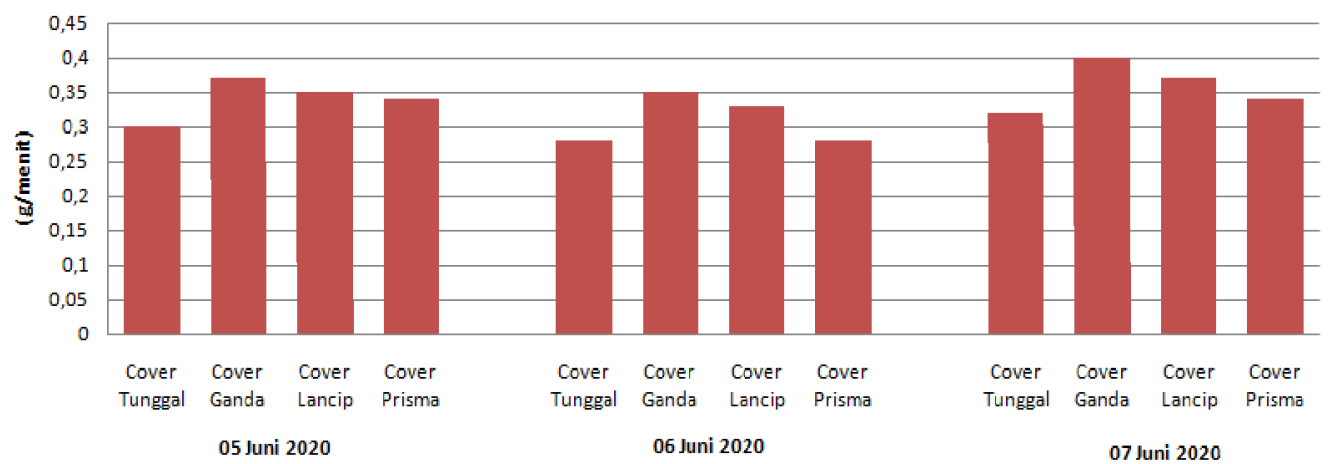

Fig 6.Graph of Drying Rate of Solar Dryer Cover Form of Drying Seaweed

Retrieval of data in Figure 6., namely 05 - 06 and 07 June 2020. On June 5, 2020 for drying using a single sloping cover, namely $0.30 \mathrm{~g} /$ minute, double sloping cover $0.37 \mathrm{~g} /$ minute, taper cover $0.35 \mathrm{~g} /$ minute and a rectangular prism cover of $0.34 \mathrm{~g} /$ minute. On June 5, 2020, the drying rate was smaller than that on July 7, 2020. This is because the weather is cloudy as shown in Figure 6, so the level of solar radiation is greater than on June 7, 2020, as shown in Figure 5, the level of solar radiation intensity on June 5 lower than the intensity of solar radiation on June 7, 2020, namely $548.88 \mathrm{~W}$ $/ \mathrm{m}^{2}$. The drying rate on June 6,2020 for single slanted cover is $0.28 \mathrm{~g} /$ minute, double slanted cover is $0.35 \mathrm{~g} /$ minute, taper cover is $0.33 \mathrm{~g} /$ minute and rectangular prism cover is $0.28 \mathrm{~g} /$ minute. This is because the intensity of solar radiation is lower than the intensity of solar radiation on other dates, namely $460 \mathrm{~W} / \mathrm{m}^{2}$. On June 7 , the drying rate is higher than on the previous date for slanted covers, the drying rate is 0.32 $\mathrm{g} / \mathrm{min}$, double slanted covers $0.40 \mathrm{~g} / \mathrm{min}$, taper covers $0.37 \mathrm{~g} / \mathrm{min}$ and rectangular prism covers $0,34 \mathrm{~g} / \mathrm{min}$. This is because on June 7, 2020 the radiation intensity is greater than the intensity of solar radiation on other dates, namely $597.77 \mathrm{~W} / \mathrm{m}^{2}$.

\section{Useful Heat Test Results}

On June 5, 2020, the highest useful heat for double slanted covers is 0.48 Watt, taper cover is $0.33 \mathrm{Watt}$, rectangular prism cover is $0.28 \mathrm{Watt}$ and single slanted cover is 0.26 Watt. On June 6, 2020 for a double slanted cover, namely 1.58 Watt, taper cover 1.12 Watt, rectangular prism cover 0.18 Watt and a single slanted cover 0.020 Watt. This is because it is influenced by the density of the air, causing the heat to be of little use. On June 7, 2020, heat is useful to have increased from the previous day, for a single slanted cover, namely $2.13 \mathrm{Watt}$, taper cover $1.46 \mathrm{Watt}$, rectangular prism cover 0.69 Watt and single sloping cover, namely 0.32 Watt. The highest useful heat is located on June 7, 2020 for a double sloping cover of 2.13 Watt. This is because the peak of solar radiation is stable and is caused by a double sloping cover curving downward so that a greater convection of radiation is absorbed by the absorbent plate. 


\section{Collector Efficiency Test Results}

On June 5, 2020 the efficiency of the absorbent collector produced by each form of seaweed dryer solar dryer cover for single sloping covers is $0.61 \%$, double slanted covers are $1.13 \%$, taper covers are $0.78 \%$ and rectangular prism covers 0 , $66 \%$. As for June 6, 2020 for single slanted covers, namely $0.056 \%$, double slanted covers $4.47 \%$, taper covers, $17 \%$, rectangular prism covers $0.50 \%$. On June 7, 2020 for single slanted cover, namely $0.69 \%$, double sloping cover $4.63 \%$, taper cover $3.18 \%$ and rectangular prism cover which is $1.50 \%$. The highest collector efficiency on June 7, 2020 lies in the double sloping cover, namely $4.47 \%$. This shows that the efficiency of the double slanted cover is more efficient than other cover forms because the double slanted cover can better convert heat radiation so that the collector is able to absorb higher heat than the other covers.

\section{Water Content Testing Results}

In the first test on $05-06$ and 07 June 2020. On 5 June 2020 the moisture content was lost on drying using a single sloping cover, namely $49.1 \%$, double slanted cover $60.6 \%, 56.3 \%$ taper cover and faceted prism cover four, namely $54.4 \%$. On the first day of testing, the peak of the highest lost water content was on a double sloping cover, namely $60.6 \%$. This is because the double sloping cover is able to convert more radiation so that the dried seaweed dries faster. On the drying on June 6, 2020 for single slanted covers, namely $46.06 \%$, double slanted covers $57.03 \%$, taper covers $53.76 \%$ and prism covers $45.86 \%$. On the second drying, the moisture content lost on the double sloping cover was smaller than the previous day. This is because on June 6, 2020 the intensity of solar radiation is smaller than on the previous day. On June 7, 2020 , the moisture content was lost for single oblique cover, namely $51.86 \%$, double slanted cover $64.83 \%$, taper cover $56.5 \%$ and rectangular prism cover, namely $55 \%$.

The peak of water content on the third day of testing is located on a double sloping cover, namely $64.83 \%$. This is because the intensity of solar radiation is normal and there is no disturbance in the circulation of air that comes out freely due to the leaking walls or drying doors.

Based on testing on $05-06$ and 07 July 2020, the remaining moisture content of seaweed on drying using a single sloping cover is $35.9 \%$, a double sloping cover is $24.4 \%$, a taper cover is $28.7 \%$ and a rectangular prism cover is $30,6 \%$. In the first test, the highest remaining peak moisture content is located on a double sloping cover of $24.4 \%$. This is because the double sloping cover is able to convert higher radiation so that the final mass of the seaweed is smaller. On June 6 , the single slanted cover was $38.94 \%$, the double slanted cover was $57.03 \%$, the taper cover was $53.76 \%$ and the rectangular prism cover was 39.14. The remaining water content of seaweed on the second drying decreased more than on the first day. This is because on June 6, 2020 the level of solar radiation experienced cloudy weather. On June 7, 2020, the remaining moisture content for single slanted cover is $33.14 \%$, double slanted cover is $20.17 \%$, taper cover is $28.5 \%$ and rectangular prism cover is $30 \%$. 


\section{CONCLUSION}

Based on the results of the research that has been done, the following conclusions are obtained:

The peak of the highest drying rate in the drying seaweed solar dryer is located on June 7, 2020, which occurs in the double sloping cover solar dryer, which is $0.40 \mathrm{~g} /$ minute. This is because on June 7, 2020 the highest peak of solar radiation intensity compared to other dates is that the convection of solar radiation is greater because it is caused by the shape of the cover curving downward. The received solar radiation intensity will pass through the transparent then the transmitted sun will be a small part of the seaweed and most of it will hit the absorbent plate. The air that enters through the temperature hole will enter the drying room so that the hot air absorbed by the absorbent plate will blow hot air throughout the drying room, the hot air will come out through the outside air temperature.

The highest peak for useful heat on June 7, 2020 lies in the double sloping cover form solar dryer, namely 3.82 Watts. While the highest drying efficiency occurred on June 7,2020 , which was located in a double sloping solar dryer with a cover of $4.47 \%$.

\section{ACKNOWLEDGMENTS}

The author is grateful to the Sumbawa University of Technology's Mechanical Engineering Study Program for supporting this research. Thanks are also conveyed to the Dean of the Faculty of Engineering and the Chancellor of the University of Technology of Sumbawa, who always provide motivation and direction in the implementation of this research so that he can express it well.

\section{REFERENCES}

[1] Youce dkk, (2013). Konstruksi dan Kapasitas Alat Pengering Ikan Tenaga Surya Sistem Bongkar Pasang, Vol 1. No.2

[2] Ketut Astawa dkk, (2015). Analisa Performansi Kolektor Surya Pelat Bergelombang Untuk Pengering Bunga Kamboja. Proceding Seminar Nasional Tahunan Teknik Mesin XIV. Banjarmasin.

[3] Ismail dan Andi Hardianto, (2016). Studi Eksperimen Bentuk Kaca Penutup Untuk Meningkatkan Produktivitas dan Efisiensi Solar Still. Edisi Khusus No.2.

[4] Abdjul dkk, (2016)."Rancang Bangun Alat Pengering Ikan Asin Efek Rumah Kaca Berbentuk Prisma Segi Empat Dengan Variasi Batu Sebagai Penyimpan Panas."Vol.1, No.1.

[5] Handoyo, (2002). Pengaruh Jarak Kaca dan Heat Absorber terhadap Panas yang diterima Heat Absorber Plate. Vol 4. No.1

[6] Dina dkk. (2018). Rancang Bangun dan Uji Coba Pengering Surya Type Kolektor Tabung Vakum Evacuated Tube Collector. Vol 29. No.1 